Received: October 9, 2015

\title{
Developing Students for University through an International High School Program in Turkey
}

\author{
Sila Sagun ${ }^{1}$ \\ Bilkent University
}

\author{
Armagan Ateskan ${ }^{2}$ \\ Bilkent University
}

\author{
Jale Onur ${ }^{3}$ \\ Maltepe University
}

\begin{abstract}
This article explores the readiness and development for universities of students who have been educated through an international program in Turkey. It compares the academic performance and skills of students who attended the Ministry of National Education High School Program (MONEP) to students who attended both MONEP and the International Baccalaureate Diploma Program (IBDP). In addition, university students' perceptions of their overall performance through the programs were analyzed. The results indicated that the MONEP and IBDP students had higher cumulative grade point averages (CPGA), higher individual course grades in their university, and a considerably higher graduation rate; the MONEP+IBDP group was three times more likely to complete their undergraduate program in four years compared to the MONEP group. Focus-group discussions further clarified the differences between the groups' academic performances and skills. Overall, the study found that the international high school education program seemed to develop a better student profile for university life.
\end{abstract}

\section{Keywords}

International education • International Baccalaureate • Academic performance $\bullet$ Critical-thinking skills • Time-management skills

1 Correspondence to: Sila Sagun, Graduate School of Education, Bilkent University, Ankara 06800 Turkey. Email: silaseverim@gmail.com

2 Graduate School of Education, Bilkent University, Ankara 06800 Turkey. Email: ateskan@bilkent.edu.tr

3 Faculty of Education, Maltepe University. Email: eddjo08@gmail.com

Citation: Sagun, S., Ateskan, A., \& Onur, J. (2016). Developing students for university through an international high school program in Turkey. Educational Sciences: Theory \& Practice, 16, 439-457. 
Access to international education has gained importance worldwide. In a globalized world, traditional education methods are found to be increasingly insufficient for educating well-rounded individuals who can contribute to their community. To develop the skills that will benefit students for the future with skills such as critical thinking or time management, more and more educators and parents believe that international education is crucial (Cole, Gannon, Ullman, \& Rooney, 2014; Walker, 2012). More than just for internationally mobile students, international education has become important to any student who would like to acquire $21^{\text {st }}$ century skills (Ramler, 1991; Rawlings, 2000).

There are different curricula used in international education, the most common in Turkey in accordance with international standards is the Diploma Programme (DP) of the International Baccalaureate ${ }^{\circledR}$ (IB). The number of national and international schools that apply DP have increased rapidly in Turkey. The problem this study attempts to tackle is how the combination of international and national curricula helps Turkish students prepare for university education. Studies exist that have compared national and international programs by exploring the views of Turkish students, teachers, and administrators; however, the number of these studies is limited (Bora, 2010; Çam Aktaş, 2013; Demirer, 2002). To understand the outcomes from the combination of national and international programs, the role of high school on university preparation needs to be investigated.

The main purpose of this study is to evaluate student readiness and development for university preparation in Turkey through international education. In addition to the academic performance of students, their skills have been evaluated to understand their readiness and development for university preparation. The skills that were selected were time management and critical thinking. These variables were used to evaluate the differences between student outcomes. Research has indicated that study skills such as time management tie to the academic performance of university students (Proctor, Prevatt, Adams, Reaser, \& Petscher, 2006). Critical thinking is described as an important skill in general education (Halpern, 2001) and is referred to as a $21^{\text {st }}$ century skill (Partnership for 21st Century Learning, [P21], 2015). Changes in organizations require changes in educational experience and skills: More and more, employers and educators have indicated the need for better critical-thinking skills in academic performance and job outcomes (Koenig et al., 2011).

In this study, the academic performance and skills of students who had attended the national high school program (MONEP) and IBDP were compared to students who had only attended the MONEP. Furthermore, the research investigated students' perceptions of their overall preparedness for university life through the questions listed below: 
a. How do university students' academic performances differ based on the high school program they attended?

b. How do university students' skills related to academic performance differ based on the high school program they attended?

c. What are university students' perceptions about their academic performance and skills within the university?

\section{International Baccalaureate Diploma Programme (IBDP)}

The IBDP is a two-year international education program for students between 16 and 19 years old. The aim of this program is to prepare students for university life. Its mission is to "develop inquiring, knowledgeable, and caring young people who will help to create a better and more peaceful world through intercultural understanding and respect" (IB, 2015a).

The IBDP consists of six subjects: studies in one's native language and literature, language acquisition (secondary language), individuals and societies, mathematics, the sciences, and the arts. There are also three core components: Theory of Knowledge, Extended Essay, and Creativity-Activity-Service. Students usually choose three (not more than four) subjects at a higher level (240 teaching hours per subject), and three others at a standard level (150 hours). Student work is assessed both internally and externally based on specific criteria (IB, 2015b).

\section{Ministry of National Education's High School Program (MONEP)}

The Turkish MONEP is a four-year program for students between 14 and 18 years old. The mission of this program is "to educate youth according to their interest, desire, and talent, as well as to contribute to the production of qualified human power as a driving force of community development" (MONE, 2015a).

MONEP consists of 14-15 common subjects and one or two elective subjects for 9th and 10th grade. In the last two years of high school, students have eight or nine subjects in common and around 10 elective courses based on their interest (MONE, 2015b). Student work is assessed internally at every grade level. At the end of 12th grade, students take the national university entrance exam. The grade one gets on this exam has a great effect on university placement compared to the high school GPA. Therefore, the format and questions on the exam have an impact on the teaching methods and applied curricula. 


\section{The IBDP in Turkey}

There are currently 39 IBDP schools in Turkey, the first one being authorized in 1994 (IB, 2015c). In IBDP schools in Turkey, students have to meet the requirements of both the IBDP and MONEP. As the cognitive demand, philosophy, and content of the two programs are different, schools may need to adjust their education system to accommodate both programs. These adjustments include extra hours of teaching as well as different teaching methods and assessment strategies. The medium of education in IBDP is English. Students are also assessed internally and externally in English except for the secondary language and literature courses. IB does not require a high level of English competency, but this situation might differ among schools in Turkey. These changes create extra work and cause stress on students that may affect their performance on the national university entrance exam, which is the basic benchmark for university placement. Currently, an IBDP diploma score does not influence university placement as it does in other countries, although Turkish IBDP schools are working informally with universities to promote gains for those who have completed the IBDP. There are some benefits to having an IBDP diploma for students in some private and non-profit foundation universities. Based on their IBDP scores, students get various financial scholarships, the chance to have a double major, and/or the ability to transfer from one department to another.

\section{Method}

This study is a mixed method research that uses the convergent parallel design. The quantitative and qualitative phases and data collection were implemented concurrently. The phases were performed independently from each other and then mixed during the interpretation of the results (Cresswell \& Plano Clark, 2011). The research design has been provided in Figure 1 below.

\section{Research Procedure}

The research began by sending invitation letters to 19 IBDP schools in Turkey in 2013. We received 16 positive responses and followed up with the IBDP coordinators

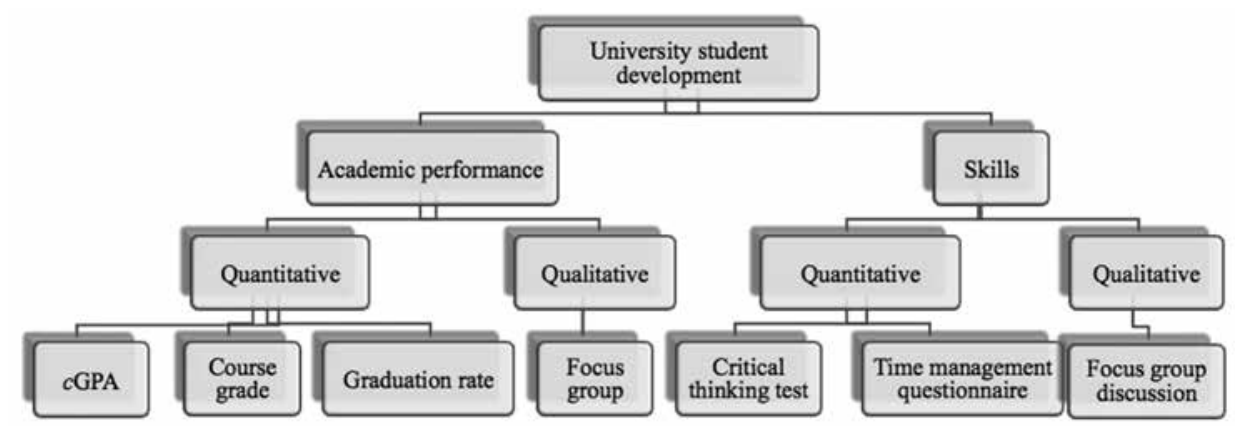

Figure 1. Research design. 
of the schools that had agreed to support the research, asking them to provide information about the university placement of their students who had graduated from 2009 to 2013 (to check the graduation rate). This data helped determine which universities were most frequently attended by MONEP+IBDP students.

The five universities that had the greatest number of MONEP+IBDP students were identified, and those universities were approached to access data about the students at the university level (CPGAs, individual class scores, graduation rate). Four of the universities agreed to collaborate, and they supplied the required data. Ethics committee approvals were obtained from these universities.

\section{Participants}

The four Turkish universities' students that had the greatest number of MONEP+IBDP students formed the sample for this study. An equal number of MONEP students were randomly selected from each university. To ensure the MONEP students had comparable parameters to the MONEP+IBDP group, we made sure they had graduated from similar types of high schools and studied in the same department.

The total number of participants for the first research question was 761. All of them were Turkish citizens. Their ages ranged from 19 to 24 years old. The distribution of participants based on their university and high school program type is shown in Table 1.

\begin{tabular}{lcc}
\hline Table 1 & & \\
Frequency of MONEP + IBDP and MONEP Students in the Four Universities & \\
\hline University & MONEP+IBDP students & MONEP students \\
\hline University 1 (Foundation) & $280(72.7 \%)$ & $268(71.2 \%)$ \\
University 2 (Public) & $51(13.2 \%)$ & $52(13.8 \%)$ \\
University 3 (Foundation) & $38(9.9 \%)$ & $40(10.7 \%)$ \\
University 4 (Foundation) & $16(4.2 \%)$ & $16(4.3 \%)$ \\
Total & 385 & 376 \\
\hline
\end{tabular}

The participants were from the faculties of engineering, science, social sciences, law, and economics. The four universities instructed in English, and all students had to pass an English proficiency test or take a year of English preparation before proceeding to their first year.

For research questions $b$ and $c$, the sample was drawn from volunteer participants (39 MONEP+IBDP and 33 MONEP students) from the two universities that had the greatest number of MONEP+IBDP students. The participants signed an informedconsent form before the phases were implemented. 


\section{Instruments}

Three data collection tools were used for the study: the Time Management Questionnaire (Britton \& Tesser, 1991), a critical thinking test, and focus group interviews.

Time Management Questionnaire (TMQ). The TMQ had 18 items and was composed of three sub-sections: short-range planning ( 7 items), time attitudes (6 items) and long-range planning (5 items). Each item had a 5-point Likert-scale (1 $=$ never : 5 = always). Five of the items $(8,10,11,13$, and 16) were negatively expressed and so were reverse-coded. Cronbach's alpha was .80 for the entire instrument. Permission was gathered from the creators of the questionnaire, and it was applied in English.

Critical-thinking test. A professional company, Corporate Executive BoardSaville and Holdsworth Limited (CEB-SHL), conducted the critical-thinking test in Turkish. This instrument had three different sections. They measured three aspects: the ability to evaluate the logic of various kinds of arguments (Verbal Critical Reasoning [VCR]), the ability to make correct decisions or inferences from numerical or statistical data (Numerical Critical Reasoning [NCR]), and the recognition of logical sequences within a series of diagrams or symbols (Diagrammatic Series [DS]; Saville \& Holdsworth Limited [SHL], 2015).

According to SHL's report, which provided detailed information regarding norms, reliability, and validity, Cronbach's alpha coefficients for the two tests used in this study were estimated as .88 for NCR and as .80 for VCR (SHL, 2015). According to Nunnally (1978), these alpha coefficients indicate an acceptable level of internal consistency. As an indication of content validity, the technical report stated that the tests had been designed with references to abilities required by qualified jobs.

Focus-group interviews. Focus-groups interviews were used to obtain the participants' perceptions, as group interaction helps the ideas of the participants to emerge (Cohen, Manion, \& Morrison, 2007). The focus-group interview questions used in this study explored the participants' perceptions about their academic performance and skills in their universities. There were eight focus groups conducted with eight or nine participants each. The sessions were in Turkish and lasted approximately 90 minutes. The moderators were experienced researchers and had had a standardization meeting before the interviews.

\section{Analysis of Data}

Quantitative data analysis. For research question $a$, the dependent variables were the participants' CPGA, average score for individual subjects (Turkish, English, mathematics, chemistry, and physics), and the graduation rate from the university after four years 
of study. To understand better their academic performance, student performance on common courses selected together with their CPGAs and graduation rates were used. The independent variable was whether they had studied at an IBDP high school or not.

Data were first analyzed by computing the means and standard deviations for each test score. Normality was checked with skewness and kurtosis values across the variables. Given that these values were between the range of -1 and +1 , data were assumed to be normal. Independent samples t-tests were used to test for the mean differences in CPGAs and individual subject scores between MONEP+IBDP and MONEP students. All tests were conducted with $a=.05$. The percentages of graduation rates of MONEP+IBDP and MONEP students were given. A chi-square test of independence was calculated for comparing the graduation rate of MONEP+IBDP and MONEP students.

Quantitative data were analyzed descriptively, including the mean and standard deviations for the Time Management Questionnaire (TMQ) and critical-thinking test scores. Independent samples t-tests were used to compare MONEP+IBDP and MONEP students' TMQ and critical-thinking test scores.

Qualitative data analysis. The common analytic approach was utilized to analyze the qualitative data (Miles \& Huberman, 1994). Recordings were first transcribed and then checked by all researchers (Creswell, 2009); while reading the transcriptions, some recurrent themes were identified. The codes were generated inductively (Strauss $\&$ Corbin, 1990). For analysis reliability, different researchers independently formed codes from the results during the coding process and then cross-checked as a group (Creswell, 2009). These codes were gathered into categories to give a general idea of the emerging themes. After the first-level of coding, all categories from each document were grouped under the major themes, which were themselves then grouped into the final themes and sub-themes given in Tables 4,7 , and 8 .

\section{Results}

\section{Academic Performance in the University}

Quantitative results. When the MONEP+IBDP students' most recent CPGAs were compared to the MONEP students, the MONEP+IBDP students in our sample had higher scores. Similar results were observed for the English course scores: MONEP+IBDP students were more successful than the MONEP students. The mean English course scores for the MONEP+IBDP students were found to be statistically significantly higher than the MONEP students mean scores.

The comparison of MONEP+IBDP students to MONEP students for the mean scores of other individual subjects (Turkish, mathematics, chemistry, and physics) 
showed no statistically significant difference between these two groups of students. Table 2 shows the mean and standard deviations for their CPGAs and the selected individual subjects.

Table 2

Mean and Standard Deviations for CGPA and the Average Scores of Individual Subjects; Turkish, English, Mathematics, Chemistry and Physics

\begin{tabular}{lccccc}
\hline & MONEP+IBDP students & MONEP students & & & \\
\hline & Mean (Standard deviation) & Mean (Standard deviation) & $\mathrm{N}$ & $\mathrm{df}$ & $t$ \\
\hline CGPA & $3.04(0.65)$ & $2.69(0.69)$ & 761 & 759 & $7.22^{*}$ \\
Turkish & $3.59(0.73)$ & $3.24(0.80)$ & 481 & 479 & 5.02 \\
English & $3.27(0.46)$ & $2.58(0.82)$ & 761 & 759 & $13.10^{*}$ \\
Mathematics & $2.49(1.06)$ & $2.32(1.17)$ & 546 & 544 & 1.80 \\
Chemistry & $2.75(0.78)$ & $2.44(0.76)$ & 90 & 88 & 1.94 \\
Physics & $2.54(0.82)$ & $2.29(0.91)$ & 306 & 304 & 2.44 \\
\hline${ }^{*} p<.05$. & & & &
\end{tabular}

Only the students who had attended a university in 2009 (N=140; 70 MONEP+IBDP students) were considered when comparing the university graduation rate. Table 3 shows the graduation rates of MONEP+IBDP and MONEP students from the 2009 attendees group.

Table 3

MONEP $+I B D P$ and MONEP students' University Graduation Rates

\begin{tabular}{lccccc}
\hline & \multicolumn{2}{c}{ MONEP+IBDP students } & \multicolumn{2}{c}{ MONEP students } \\
\hline & & Frequency & $\%$ & Frequency & $\%$ \\
\hline \multirow{2}{*}{ Graduation rate } & No (Not in 4 years) & 27 & 38.6 & 54 & 77.1 \\
& Yes (In 4 years) & 43 & 61.4 & 16 & 22.9 \\
\hline \multicolumn{2}{l}{ Total } & 70 & 100 & 70 & 100 \\
\hline Chi-square $=0.001 *$ & & & & \\
\hline$* 0.05$.
\end{tabular}

A chi-square test of independence was calculated by comparing the graduation rate of MONEP+IBDP students to MONEP students. A significant interaction was found, $(1, \mathrm{~N}=70)=0.001, p<.05$. The MONEP+IBDP students were more likely to graduate $(61.4 \%)$ than the MONEP students $(22.9 \%)$ in their fourth year. For the remainder of both groups, it took longer than four years to graduate. No one had dropped out of their university in either of the groups.

Qualitative results. The major findings of the perceptions of MONEP+IBDP and MONEP students about their academic performance in the university were explored under two major themes: the effect of their high school program and their current experiences in university related to their academic performance. The themes and subthemes are given in Table 4. 


\begin{tabular}{|c|c|c|}
\hline \multicolumn{3}{|c|}{$\begin{array}{l}\text { Table } 4 \\
\text { Major findings of the perceptions of MONEP+IBDP and MONEP students about their academic perfor- } \\
\text { mance }\end{array}$} \\
\hline & MONEP+IBDP students & MONEP students \\
\hline $\begin{array}{l}\text { The effect of } \\
\text { their high school } \\
\text { program }\end{array}$ & $\begin{array}{l}\text { Positive } \\
\cdot \text { acquired critical thinking skills } \\
\cdot \text { self-confidence } \\
\cdot \text { completed both MONEP and IBDP } \\
\cdot \text { learned how to answer questions } \\
\text { Negative } \\
\cdot \text { didn't help improve regular study habits }\end{array}$ & $\begin{array}{l}\text { Positive } \\
\cdot \quad \text { were better prepared for mathematics/ } \\
\text { science } \\
\text { Negative } \\
\cdot \quad \text { didactic } \\
\cdot \quad \text { chronological } \\
\cdot \quad \text { education system different } \\
\cdot \quad \text { training for exams }\end{array}$ \\
\hline $\begin{array}{l}\text { Current expe- } \\
\text { riences at uni- } \\
\text { versity }\end{array}$ & $\begin{array}{l}\text { Positive } \\
\text {. intend to enter more courses } \\
\text {. don't have to work hard to pass } \\
\text {. timesaving (similar course materials and } \\
\text { books) } \\
\text { Negative } \\
\cdot \text { lots of homework }\end{array}$ & $\begin{array}{l}\text { Positive } \\
\cdot \quad \text { applied classes at university } \\
\cdot \text { lots of homework } \\
\cdot \quad \text { critical and analytical } \\
\text { Negative } \\
\cdot \quad \text { concerned about grades }\end{array}$ \\
\hline
\end{tabular}

MONEP+IBDP students' perceptions about the effect of their high school programs were mostly positive. They claimed positive changes in self-confidence, especially in language competency, as well as the acquisition of critical-thinking skills. Being part of MONEP and IBDP at the same time had helped them to succeed on the university entrance exam and IBDP simultaneously. They were also happy with their academic skills in answering exam questions. This was clarified by one MONEP+IBDP student:

For example, one of the biggest skills we gained in IBDP was how to answer a question fully in the clearest, most-concise way. This has been very beneficial for me on the exams. I had gained this skill in high school; not in high school, actually, but in the IBDP.

MONEP students' perceptions about the effect of their high school program were generally negative. They stated that the didactic education system in high school was very different from the university system and therefore did not help them in the university except for training them for the national university entrance examinations. They indicated that high school had prepared them better for mathematics and science than it had for languages and the social sciences.

MONEP+IBDP students agreed about the lack of novelty, rigor, and challenges regarding their current experiences in the university. Because of this, they tended to take on extra courses. MONEP+IBDP students expressed "Some of my classmates had a hard time completing assignments in the $1^{\text {st }}$ and $2^{\text {nd }}$ year that were very easy for me to complete because of the courses I had taken in high school."

MONEP+IBDP students mentioned "lots of homework in the university" as a negative factor, while MONEP students' perceptions looked at it differently as an opportunity to improve their academic skills. A MONEP student in one of the focus- 
group discussions said, "I got homework almost every day. This keeps me on task and aware of the topic far before the exams." This is in line with the study habits they had acquired in high school. However, they were frustrated with the grading system because of the stress it created.

\section{Skills}

The time management and critical thinking skills of MONEP+IBDP and MONEP students were analyzed both quantitatively and qualitatively.

\section{Quantitative results.}

Time management skills. The descriptive analysis results of the Time Management Questionnaire (TMQ) for MONEP+IBDP and MONEP students are given in Table 5.

Table 5

$T M Q$ Results for MONEP $+I B D P$ and MONEP Students

\begin{tabular}{lccccc}
\hline \multicolumn{5}{c}{ MONEP students } \\
\hline & Mean (Standard deviation) & Mean (Standard deviation) & $\mathrm{N}$ & df & $t$ \\
\hline TMQ average & $3.06(0.56)$ & $2.92(0.49)$ & 81 & 79 & 1.178 \\
\hline$* p<.05$.
\end{tabular}

The mean TMQ scores of MONEP+IBDP students were not found to be significantly different from those of MONEP students. Although not statistically significant, the results showed that MONEP+IBDP students were slightly better at managing their time than MONEP students.

Critical-thinking skills. Data from the critical-thinking test were analyzed descriptively, including the mean and standard deviation for the scores from the Numerical Critical Reasoning (NCR), Verbal Critical Reasoning (VCR), and Diagrammatical Series (DS) tests for MONEP+IBDP and MONEP students. The descriptive analysis results from the critical-thinking skills test for MONEP+IBDP and MONEP students are given in Table 6.

\begin{tabular}{|c|c|c|c|c|c|}
\hline $\begin{array}{l}\text { Table } \\
\text { Critic }\end{array}$ & kills Test Results for MONE & BDP and MONEP Students & & & \\
\hline & MONEP+IBDP students & MONEP students & & & \\
\hline & Mean (Standard deviation) & Mean (Standard deviation) & $\mathrm{N}$ & df & $t$ \\
\hline NCR & $18.36(5.48)$ & $20.18(5.76)$ & 72 & 70 & -1.373 \\
\hline VCR & $34.46(3.66)$ & $35.82(4.53)$ & 72 & 70 & -1.405 \\
\hline DS & $28.64(5.20)$ & $29.70(5.27)$ & 72 & 70 & -0.852 \\
\hline
\end{tabular}

The MONEP+IBDP students' NCR, VCR, and DS mean scores were not found to be significantly different from the MONEP students' mean scores. 


\section{Qualitative results.}

Time management skills. The major findings of the perceptions of MONEP+IBDP and MONEP students about their time management skills were categorized into three main themes: the definition and techniques of time management, the effect of the high school program, and current experiences in the university. The themes and subthemes are given in Table 7.

\begin{tabular}{|c|c|c|}
\hline \multicolumn{3}{|c|}{$\begin{array}{l}\text { Table } 7 \\
\text { Major Findings of the Perceptions of MONEP+IBDP and MONEP Students About Their Time Management Skills }\end{array}$} \\
\hline & MONEP+IBDP students & MONEP students \\
\hline $\begin{array}{l}\text { Definition and } \\
\text { techniques of } \\
\text { time manage- } \\
\text { ment }\end{array}$ & $\begin{array}{l}\text { meet due dates } \\
\text { be calm } \\
\text { be active } \\
\text { organization/technology usage } \\
\text { prioritization } \\
\text { working in library }\end{array}$ & $\begin{array}{l}\text { using scarce resources efficiently } \\
\text {. flexibility } \\
\text {. control } \\
\text { balance } \\
\text { planning } \\
\text { prioritization } \\
\text { daily/monthly planning } \\
\text { to do list }\end{array}$ \\
\hline $\begin{array}{l}\text { The effect of } \\
\text { their high school } \\
\text { program }\end{array}$ & $\begin{array}{l}\text { Positive } \\
\cdot \text { multitasking } \\
\cdot \text { crisis management } \\
\cdot \text { extended essay } \\
\cdot \text { prioritization } \\
\text { Negative } \\
\cdot \text { no regular study habits } \\
\cdot \text { national university entrance examination }\end{array}$ & $\begin{array}{l}\text { Positive } \\
\text { no positive comments } \\
\text { Negative } \\
\cdot \text { no advanced organizer } \\
. \quad \text { no room for self-planning }\end{array}$ \\
\hline $\begin{array}{l}\text { Current expe- } \\
\text { riences in the } \\
\text { university }\end{array}$ & $\begin{array}{l}\text { Positive } \\
\cdot \text { organized instructors } \\
\cdot \text { study better at university } \\
\cdot \quad \text { university schedule } \\
. \quad \text { attendance requirement } \\
\text { Negative } \\
. \quad \text { no negative comments }\end{array}$ & $\begin{array}{l}\text { Positive } \\
\cdot \text { no positive comments } \\
\text { Negative } \\
\cdot \text { high/unrealistic expectations } \\
\cdot \text { stress }\end{array}$ \\
\hline
\end{tabular}

MONEP+IBDP students defined time management as "deadlines, meeting due dates, being calm, and getting things done," whereas MONEP students defined time management in terms of "flexibility, control, balance, and planning." As a time management strategy, MONEP+IBDP students stated that they had used organization and prioritization techniques. Only a few MONEP students mentioned that they had made prioritized "to do" lists compared to MONEP+IBDP students. Furthermore, the MONEP+IBDP students highlighted that they had used other strategies, such as using scarce resources efficiently, daily or monthly planning, and making "to do" lists.

MONEP+IBDP and MONEP students both had positive and negative views about the effects of their high school program on their development. The MONEP+IBDP students mentioned how extended essays and individual IBDP subjects had helped them to cope with time management issues later on in the university. They also thought that they were good at crisis management and multitasking because they had had to meet the requirements of two programs (MONEP and IBDP) together, and had 
completed many tasks at the same time. This also was viewed negatively, as some MONEP+IBDP students pointed out that it had hindered regular study habits in high school because of the extra amount of work because IBDP is an additional program from MONEP. Plus, they had had to study for the national university entrance exam.

MONEP students mentioned that there had been no time-management training in high school. Their teachers or family had planned their time for them beforehand, so they had never had the opportunity to plan activities for themselves. A MONEP student stated in a focus group discussion:

The difference was that in high school, I lived in a dorm. It has a certain system you must follow whether you want to or not. The teacher schedules your time. You do the same work on Wednesdays in November and Wednesdays in May.

MONEP+IBDP and MONEP students had quite different perspectives on their current experiences in the university. MONEP+IBDP students had no negative comments, while MONEP students' comments were all negative. MONEP+IBDP students acknowledged their helpful instructors, liberty to choose their own schedule, and ability to allocate time for extracurricular activities. The attendance requirement also helped them to adhere to their timetable. MONEP students complained about the university's high and unrealistic expectations. Due to stress, they were poor at time management, trying to accomplish their assignments in a rush with no time to review.

Critical thinking skills. The major findings of MONEP+IBDP and MONEP students' perceptions of their critical-thinking skills were categorized into three main themes: the concept of critical thinking, the effect of their high school program, and their current experiences in the university. The themes and sub-themes are given in Table 8.

Table 8

Major Findings of the Perceptions of MONEP+IBDP and MONEP Students about their Critical Thinking Skills

\begin{tabular}{|c|c|c|}
\hline & MONEP+IBDP students & MONEP students \\
\hline $\begin{array}{l}\text { Concept of criti- } \\
\text { cal thinking }\end{array}$ & $\begin{array}{l}\text { analysis } \\
\text {. } \text { creativity } \\
\text {. finding solutions } \\
\text {. questioning } \\
\text { different perspectives }\end{array}$ & $\begin{array}{l}\text { analysis } \\
\text { values of others' ideas }\end{array}$ \\
\hline $\begin{array}{l}\text { The effect of } \\
\text { their high school } \\
\text { program }\end{array}$ & $\begin{array}{l}\text { Positive } \\
\cdot \quad \text { IBDP core requirements } \\
\cdot \quad \text { science exam questions } \\
\cdot \quad \text { additional subjects } \\
\cdot \quad \text { holistic curriculum } \\
\text { Negative } \\
\cdot \quad \text { no negative comments }\end{array}$ & $\begin{array}{l}\text { Positive } \\
\cdot \quad \text { class discussion } \\
\cdot \quad \text { used depending on the teacher } \\
\text { Negative } \\
\cdot \quad \text { curriculum } \\
\cdot \text { memorization } \\
\cdot \text { exam oriented } \\
\cdot \quad \text { didactic }\end{array}$ \\
\hline $\begin{array}{l}\text { Current expe- } \\
\text { riences in the } \\
\text { university }\end{array}$ & $\begin{array}{l}\text { Positive } \\
\cdot \quad \text { no positive comments } \\
\text { Negative } \\
\cdot \text { memorization } \\
\cdot \quad \text { no evaluation level questions }\end{array}$ & $\begin{array}{l}\text { Positive } \\
\cdot \text { in-class discussions improves critical } \\
\text { thinking skills } \\
\cdot \text { research (technology, internet) } \\
\text { Negative } \\
\cdot \quad \text { no negative comments } \\
\end{array}$ \\
\hline
\end{tabular}


When MONEP+IBDP students were asked to define critical thinking, a member from the focus-group discussions stated:

According to my definition, critical thinking is to think about alternatives and to analyze the positive aspects and challenges when information is provided to you before accepting it as it is. Furthermore, if I accept it, what other options will I be ignoring? This is not just for class, it is also for daily life.

In addition, they easily provided examples of different activities that helped them improve their critical thinking skills, such as movies, taking philosophy courses, and class debates and discussions.

The MONEP students were not comfortable defining critical thinking. This group's members readily accepted the definition given by one of the interviewees without any elaboration. One MONEP student in a focus-group discussion stated, "When my friends criticize me, I consider their viewpoint; however, if I think that I am right on one point, I am hesitant to accept their views." While the first part of this sentence readily confirmed their acceptance behavior, the second part may have indicated their being closed to discussion about and acceptance of other perspectives.

MONEP+IBDP students were very positive about the effect of their high school programs regarding critical-thinking skills. They were able to give examples of how IBDP courses such as Theory of Knowledge, Turkish, and English had helped them write essays and other assignments in the university. The examples were not only from language courses. They appreciated questions that required reflection, and IBDP had developed their critical-thinking skills in science and math. One MONEP+IBDP student gave an example of this perspective: "No physics or mathematics questions were solved directly with formulas. You needed to think first about whether variables should be included or calculated."

The MONEP students were more negative about the effect of their high school program. They highlighted the national university entrance examination as the cause of the didactic system in their high schools. MONEP students said that they had memorized information to be successful on the national university entrance examin. One MONEP student said, "We learned the information in the way that would be asked on the exam (multiple-choice questions) instead through discussion. It is different in the university. We have experienced the gap between high school and university education."

In respect to their current experiences in the university, the perceptions of MONEP+IBDP and MONEP students differed. MONEP+IBDP students' perceptions were all negative, contrary to MONEP students', who were all positive. MONEP+IBDP students criticized assignments that fostered memorization in the university while 
MONEP students liked the lectures, assignments, and research possibilities in the university. MONEP students reported that in-class discussions had helped to improve their critical-thinking skills. MONEP+IBDP students stated that university courses were based on memorization, that they had been using didactic teaching approaches, and that exam questions did not foster critical-thinking skills.

\section{Discussion, Conclusion and Suggestions}

This study has explored the developments for university preparation of students who had been educated through the international program in Turkey. To accomplish this aim, we compared students who had followed both MONEP and IBDP, as well as students who had followed only MONEP. The students' academic performances and skills were compared to have an understanding of their readiness and development for university life.

With regard to the academic performance of the two groups, MONEP+IBDP students' CPGAs were significantly higher than MONEP students'. Additionally, MONEP+IBDP students outperformed MONEP students in a variety of universitylevel courses. The biggest difference between them was in English, followed by Turkish, chemistry, physics, and mathematics. When the graduation rates for the group who had attended universities in 2009 were compared, it was clear that nearly three times as many MONEP+IBDP students (61.4\% vs. 22.9\%) had completed their university in their fourth year. This result could be attributed to their general education, passing the English preparation-year exam, and/or the study skills that they had developed in the IBDP.

One possible explanation for these differences is that MONEP and IBDP together prepare students better for university studies (IB Research Team, 2007; Saavedra, Lavore, \& Flores, 2013; Shah, Dean, \& Chen, 2010). During their high school years, MONEP+IBDP students had had opportunities to process information themselves with enough time to practice their academic skills. Another possible explanation related to the above point is the difference between the philosophies of the two programs. Because the two programs have different teaching approaches, students have had to incorporate both into their learning processes. MONEP's emphasis on knowledge accumulation in the courses offered outnumbered IBDP. IBDP chose to emphasize character-building, academic, and life skills while limiting the number of offered courses to only six (MacKenzie, 2000).

The MONEP aims to build habits by the use of didactic methodology heavily based on a scholar academic ideology. For example, it prohibits the use of calculators and expects students to do mathematical calculations in their head. Furthermore, students are expected to learn all scientific and mathematical formulae by heart so that they can answer the more important university-entry test questions quickly and 
consistently. This is one of the biggest differences between IBDP and MONEP. A possible explanation for this difference might be teachers' experience and the smaller class size in IBDP (Paris, 2003). There may also be differences in parents' literacy and socioeconomic status.

Along with the quantitative facts given above, this study explained students' perceptions about their academic performance for both MONEP+IBDP and MONEP students. The results found that MONEP+IBDP students valued their high school education and had highlighted the effect it had on their academic performance in the university. Mainly, they reported the similar academic approaches used both in high school and in the university. MONEP+IBDP students lacked regular study habits because they had had to complete both curricula requirements at the same time. However, this had helped them to learn multi-tasking.

MONEP students did not value their high school education, especially with regard to languages, but they were satisfied with their preparedness in mathematics and science. Since the approach to learning was quite different in high school than in their universities, they had struggled with the new academic skills and habits that they needed to develop.

Another dimension of the study was related to the academic skills of MONEP+IBDP and MONEP students. The results of the quantitative study showed no significant difference between the time-management and critical-thinking skills of two groups. However, their perceptions about these skills were different in many ways. As MONEP+IBDP students had had to follow both programs at the same time, they were required to be good at managing their time. In particular, the IBDP program had deadlines the students were required to meet (deadlines for extended essays, internal assessments, or Theory of Knowledge [TOK] assignments), which helped promote these students' time-management skills. Although both groups claimed that they did not have regular study habits, MONEP+IBDP students argued the programs' tasks had forced them to multi-task. MONEP students did not have many required due dates or longitudinal studies throughout their high school education. Most of the time, their parents and/or teachers prepared their schedules for them. This was not a help in building time-management skills.

In terms of critical-thinking skills, the majority of MONEP+IBDP students considered themselves as critical thinkers, whereas MONEP students had had a hard time defining what critical thinking was. MONEP+IBDP students highlighted the importance of the TOK course they studied in IBDP. The subject guide for TOK (IB, 1987) states that TOK is central to the educational philosophy of the IB. Among its aims are "developing an understanding of why critically examining knowledge claims are important, and developing a critical capacity to evaluate beliefs and knowledge 
claims" (Mackenzie, 2000, p. 46). The MONEP+IBDP students who had attended the focus-group discussions exhibited these characteristics. However, the MONEP group did not exhibit the same relaxed type of brainstorming approach nor did they offer their opinions; they showed a tendency of readily accepting the first definition or statement made by their friends. They stated that their high school program had not prepared them for the critical approach required in a university. Even though there were no significant differences between their critical-thinking skills and test scores, their responses in the focus-group discussions were quite different. The format for the critical-thinking skills tests used multiple-choice questions; however, MONEP+IBDP students were not used to this style of assessment. This might explain the different results in the quantitative and qualitative analyses.

Similar to this study, Taylor and Porath (2006) found that IBDP students in Canada had positive feelings about their developments: The students believed that they had been exposed to a rich curriculum and that by the end of the program they had acquired better critical and time-management skills. They also claimed they had had more opportunities to prepare well for postsecondary studies compared to the normal high school program (Taylor \& Porath, 2006). Demir (2009) explained that students, teachers, administrators, and parents in Turkey all agreed on the positive effect of IBDP on students' critical-thinking skills. Students mentioned that the program had supported university life and had prepared students better by helping them gain organizational skills due to their being challenged to study both national and international curricula. Although MONEP and IBDP do not overlap perfectly, the combination of which creates a heavy load on students, the administration does accept the positive effects of a combined curricula on academic performance. Bayülgen (2012) also found a significant difference between IBDP+MONEP students' and MONEP students' critical-thinking skills.

The development of students' critical-thinking skills has been discussed by other researchers. Çam Aktaş (2013) compared the IBDP language A1 course with the Turkish Literature, Language, and Expression course in terms of critical thinking because it was assumed that teaching critical-thinking skills in language courses is reasonable. When IBDP courses are compared to MONEP courses, more activities such as in-class discussions and comparison making are carried out in IBDP lessons in order to promote critical thinking skills. It has been argued that IBDP better assists the development of critical-thinking skills, but no significant difference was found between IBDP+MONEP and MONEP students.

Based on these findings, suggestions for the Ministry of National Education (MONE) include the following: reduce the use of didactic methods in teaching, reduce the use of multiple-choice tests for assessment, and use a more student- 
centered method when teaching the native and secondary languages. There are also suggestions for universities that have MONEP+IBDP students. Because these students had found the first two years of the program to lack challenges, they could get credits from the Turkish universities they attend based on their IB diploma scores so that they can graduate from the university earlier. Another suggestion is that school and university administrators could be more aware of the need to improve students' time-management skills. Parents and teachers should be conscious about giving the responsibility of time management to the students themselves.

When we evaluated the quantitative and qualitative results holistically, we concluded that IBDP better prepares students for university life in terms of academic performance and skills compared to MONEP. The quantitative analysis of MONEP+IBDP students' CPGAs and individual course grades were higher than MONEP students'. The qualitative findings of behavior and the statements from the two groups in the focus groups indicated better critical-thinking skills and superior performance in the use of language for MONEP+IBDP students. Such data can help explain the two groups' difference in performance by helping us arrive at the conclusion that the education they had received in high school played an important role in whether they could use their potential effectively. As a conclusion, the international education program (IBDP) was observed to help students enhance their abilities and convert them into skills that can help them in university life.

This article explored the preparedness and development for university of students who had been educated through an international program in Turkey. Further research could be done related to their readiness and development for career life. Possible explanations for MONEP+IBDP groups' difference in graduation rate could be explored. Additionally, a study could be done with MONEP+IBDP students that have gone abroad as part of their university education.

\section{References}

Bayülgen, N. (2012). Uluslararası bakalorya programı Türkçe Al dersi alan öğrenciler ile genel program Türk edebiyatı dersi alan öğrenciler arasındaki bilişsel ve duyuşsal becerilerin karşılaştırılması [A comparison of cognitive and affective skills between students who have attended the International Baccalaureate (IB) Turkish A1 course and students who have attended the Turkish literature course of the general program] (Doctoral dissertation, Uludağ University, Bursa, Turkey). Retrieved from https://tez.yok.gov.tr/UlusalTezMerkezi/

Bora, N. (2010). Uluslararası bakalorya diploma programının (IB) öğretmen ve öğrencilerin iklimi ile ilgili algllarl üzerindeki etkisi [Impact of the IB diploma program on teacher and students' perceptions related to region] (Master's thesis, Maltepe University, İstanbul, Turkey). Retrieved from https://tez.yok.gov.tr/UlusalTezMerkezi/

Britton, B., \& Tesser, A. (1991). Effects of time-management practices on college grades. Journal of Educational Psychology, 83(3), 405-410. 
Cohen, L., Manion, L., \& Morrison, K. (2007). Research methods in education. New York, NY: Routledge.

Cole, D. R., Gannon, S., Ullman, J., \& Rooney, P. (2014). IB programme: Theory of knowledge (TOK): Exploring learning outcomes, benefits, and perceptions. Retrieved from http:// www.ibo.org/globalassets/publications/ib-research/dp/tokfinalreport_000.pdf

Creswell, J. W. (2009). Research design: Qualitative, quantitative, and mixed methods approaches (3rd ed.). Los Angeles, CA: Sage.

Creswell, J. W., \& Plano Clark, V. L. (2011). Designing and conducting mixed methods research (2nd ed.). Thousand Oaks, CA: Sage.

Çam Aktaş, B. (2013). Ortaögretimde uluslararası bakalorya programı ile ulusal programdaki anadil öğretimi derslerinin eleştirel düşünme becerileri açısından karşılaştırılması [Comparison in terms of critical-thinking skills of the national native language classes with the IB program] (Doctoral dissertation, Anadolu University, Eskişehir, Turkey). Retrieved from https://tez.yok.gov.tr/UlusalTezMerkezi/

Demir, N. K. (2009). Uluslararası bakalorya diploma programına ilişkin yönetici, öğretmen, veli ve mezun görüşleri [Views of administrators, teachers, parents, and alumni related to the IBDP] (Doctoral dissertation, Ankara University, Ankara, Turkey). Retrieved from https://tez.yok.gov.tr/UlusalTezMerkezi/

Demirer, V. (2002). Uluslararası bakalorya (IB) programı uygulayan özel okullarda çalışan öğretmenlerin bu programa karşı olan tutumlarının iş tatminlerine yansıması [Reflections of the job-satisfaction attitudes of teachers employed in schools that implement the IB program] (Master's thesis, Anadolu University, Eskişehir, Turkey).Retrieved from https:// tez.yok.gov.tr/UlusalTezMerkezi/

Halpern, D. F. (2001). Assessing the effectiveness of critical thinking instruction. Journal of General Education, 50, 270-286.

International Baccalaureate ${ }^{\circledR}$ [IB] (1987). General Guide (5th ed.). Geneva: Author.

International Baccalaureate ${ }^{\circledR}$. (2015a). The IB Diploma Programme. Retrieved from http:// www.ibo.org/en/about-the-ib/mission

International Baccalaureate ${ }^{\circledR}$. (2015b). The IB Diploma Programme. Retrieved from http:// www.ibo.org/en/programmes/diploma-programme/curriculum/

International Baccalaureate ${ }^{\circledR}$. (2015c). Information for Turkey. Retrieved from http://www. ibo.org/about-the-ib/the-ib-by-country/t/turkey/

International Baccalaureate ${ }^{\circledR}$ Research Team. (2007). School-university transition project. Summary report. Retrieved May 2015 from http://www.ibo.org/contentassets/ d74675437b4f4ab38312702599a432f1/school-universitytransitionprojectreportfinal.pdf

Koenig, J. A., Herman, J. L., Duncan, G. J., Knapp, D. J., Kyllnonen, P. C., Sackett, P. R., . . . Iverson, K. (2011). Assessing 21st century skills: Summary of a workshop. Washington, DC: National Academies Press.

Mackenzie, J. (2000). Curricular interstices and the Theory of Knowledge. In M. Hayden \& J. Thompson (Eds.) International schools and international education: Improving teaching, management and quality (pp. 43-46). London, England: Kogan Page.

Miles, M. B., \& Huberman, A. M. (1994). Qualitative data analysis: An expanded sourcebook (2nd ed.). Thousand Oaks, CA: Sage.

Ministry of National Education. (2015a). Ministry of National Education, General Directorate of Secondary Education. Mission and vision. Retrieved from http://ogm.meb.gov.tr/www/ misyon-ve-vizyon/icerik/53 
Ministry of National Education. (2015b). Weekly high school schedules. Retrieved from http:// ttkb.meb.gov.tr/www/haftalik-ders-cizelgeleri/kategori/7

Nunnally, J. C. (1978). Psychometric theory (2nd ed.). New York, NY: McGraw-Hill.

Partnership for $21^{\text {st }}$ Century Learning (2015). Framework for $21^{\text {st }}$ Century Learning. Retrieved from http://www.p21.org/about-us/p21-framework

Paris, P. G. (2003). The International Baccalaureate: A case study on why students choose to do IB. International Education Journal, 4(3), 232-243.

Proctor, B. E., Prevatt, F. F., Adams, K. S., Reaser, A., \& Petscher, Y. (2006). Study skills profiles of normal-achieving and academically-struggled college students. Journal of College Student Development, 47(1), 37-51.

Ramler, S. (1991). Global education for the 21st century. Educational Leadership, 48(7), 44-46.

Rawlings, F. A. (2000). Globalization, curriculum and international communities: A case study of the United World College of the Atlantic (Doctoral dissertation abstract). International Journal of Educational Development, 20(4), 365-366.

Saavedra, A., Lavore, E., \& Flores, G. (2013). The International Baccalaureate Diploma Programme in Mexico as Preparation for Higher Education. Santa Monica, CA: RAND Education.

Saville and Holdsworth Limited. (2015). Management and Graduate Item Bank 1-4. Surrey: SHL.

Shah, S., Dean, M., \& Chen, Y. C. (2010). Academic performance of IB students entering the University of California System from 2000-2002. Geneva, Switzerland: IB.

Strauss, A., \& Corbin, J. (1990). Basics of qualitative research: Grounded theory procedures and techniques. Newbury Park, CA: Sage.

Taylor, M. L., \& Porath, M. (2006). Reflections on the IB program: Graduates' perspectives. Prufrock Journal, 17(3), 149-158.

Walker, G. (2012). Tea and oysters: Metaphors for a global education. International Schools Journal, 31(2), 8-17. 
